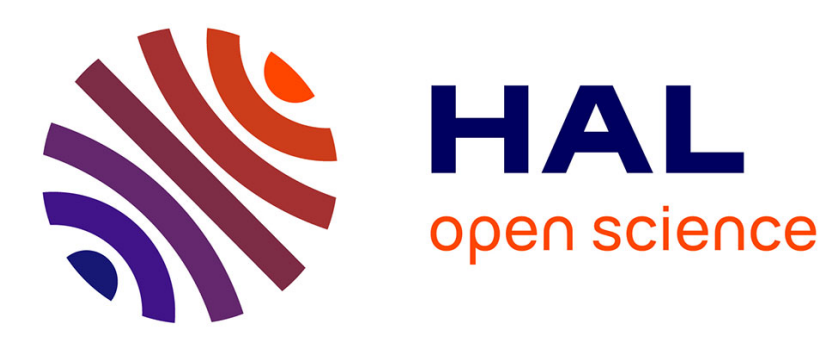

\title{
Do exchange rates have any impact upon UK inward foreign direct investment?
}

\author{
Andrew James Abbott, Glauco de Vita
}

\section{To cite this version:}

Andrew James Abbott, Glauco de Vita. Do exchange rates have any impact upon UK inward foreign direct investment?. Applied Economics, 2008, 39 (20), pp.2553-2564. 10.1080/00036840600749748 . hal-00582013

\section{HAL Id: hal-00582013 \\ https://hal.science/hal-00582013}

Submitted on 1 Apr 2011

HAL is a multi-disciplinary open access archive for the deposit and dissemination of scientific research documents, whether they are published or not. The documents may come from teaching and research institutions in France or abroad, or from public or private research centers.
L'archive ouverte pluridisciplinaire HAL, est destinée au dépôt et à la diffusion de documents scientifiques de niveau recherche, publiés ou non, émanant des établissements d'enseignement et de recherche français ou étrangers, des laboratoires publics ou privés. 


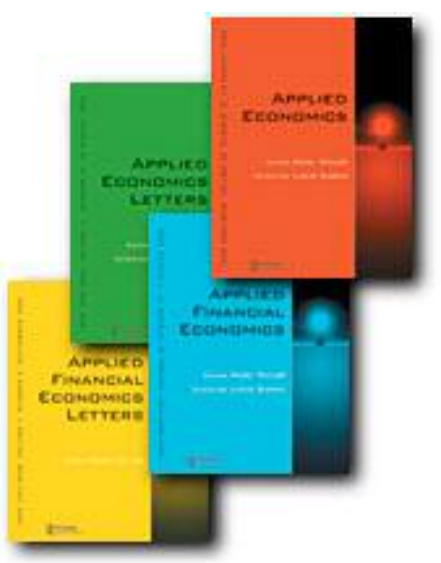

Do exchange rates have any impact upon UK inward foreign direct investment?

\begin{tabular}{|r|l|}
\hline Journal: & Applied Economics \\
\hline Manuscript ID: & APE-05-0639.R1 \\
\hline Journal Selection: & Applied Economics \\
\hline JEL Code: & $\begin{array}{l}\text { F21 - International Investment } \mid \text { Long-Term Capital Movements }<\text { F2 } \\
\text { International Economics, F31 - Foreign Exchange }<\text { F3 - } \\
\text { International Finance }<\text { F - International Economics }\end{array}$ \\
\hline Keywords: F - & $\begin{array}{l}\text { Foreign direct investment , real exchange rate, exchange rate } \\
\text { volatility }\end{array}$ \\
\hline
\end{tabular}

powered by ScholarOne

Manuscript Central ${ }^{\text {TH}}$ 


\title{
Do exchange rates have any impact upon UK inward foreign direct investment?
}

\author{
Glauco De Vita ${ }^{a}$ and Andrew Abbott ${ }^{b}$ \\ ${ }^{a}$ Oxford Brookes University Business School, Wheatley Campus, Oxford, OX33 \\ $1 H X, U K$ \\ ${ }^{\mathrm{b}}$ University of Bath, Department of Economics and International Development, \\ Bath, BA2 7AY, UK
}

\begin{abstract}
This paper examines the impact of the level and volatility of the real exchange rate on UK foreign direct investment (FDI) inflows from the seven major countries of origin of the investment over the period 1975 to 2001 . We use both fixed effects and dynamic generalised methods of moments (GMM) panel estimation techniques, and manufacturing data disaggregated by high and low $R \& D$ content of the sector of destination. Our results provide strong evidence that exchange rate volatility has a negative impact on FDI flows into the UK, irrespective of the sector of destination of the investment. On the other hand, the level of the real exchange rate is found to have a statistically insignificant effect on FDI after controlling for endogeneity of the regressors.
\end{abstract}

JEL classification: F21, F31

Keywords: Foreign direct investment; real exchange rate; exchange rate volatility

* Corresponding author. Dr A J Abbott, Department of Economics and International Development, University of Bath, Bath, BA2 7AY, e-mail: a.abbott@bath.ac.uk 


\section{Introduction}

Since the 1990s, foreign direct investment (FDI) has expanded rapidly in the UK, with the manufacturing sector becoming increasingly attractive to foreign investors. Figure 1 charts the inward FDI flows from the UK's seven main countries of origin of the investment over the period 1974 to 2001 . Up until the early 1990 s, FDI inflows were, in real terms, fairly constant, averaging $£ 1631$ millions per annum. Between 1992 and 2001, however, inward FDI flows averaged $£ 5124 \mathrm{~m}$ per annum, reaching a peak of $£ 10030 \mathrm{~m}$ in 2001 . The largest increases occurred from 1997 onwards and were particularly pronounced in the high R\&D sectors.

\section{Figures 1 and 2 near here}

In this paper we wish to establish whether the level and volatility of the real exchange rate have had a significant influence on UK's FDI inflows from 1975 to 2001. As we discuss in section 2, theoretical models examining the impact of the exchange rate on FDI generate competing predictions, and although figure 2 would suggest that movements in the exchange rate may be an important factor in explaining UK's FDI inflows, empirical studies, the vast majority of which have concentrated on the US experience ${ }^{1}$, have to date failed to conclusively establish this connection.

Given the purpose of this study, our analysis is best served by data of FDI disaggregated by country of origin. We focus on the seven major investing countries in the UK, namely the USA, France, Germany, the Netherlands, Switzerland, Australia and Japan. Collectively, these countries represent $76 \%$ of all UK inward FDI in manufacturing over the sample period.

\footnotetext{
${ }^{1}$ To the authors' knowledge, the only published study examining the determinants of inward FDI into the UK is that by Pain (1993). However, in his analysis, the only exchange rate variable considered is the rate of change of the exchange rate.
} 
Our contribution adds to previous literature in several ways. First, many researchers investigating the relationship between FDI and exchange rates have based their regressions only on the few exchange rate variables of interest (see, for example, Amuedo-Dorantes and Pozo, 2001, and Chakrabarti and Scholnik, 2002) hence failing to account for all the other factors previously identified as potential determinants of FDI. Although our interest centres upon the impact of the level and volatility of the exchange rate, we attempt to control for most of the variables typically found to have explanatory power in the determination of FDI, including those pertaining to features of the country of origin of the investment. Second, only scant attention has been paid in the empirical literature to the R\&D content of FDI. This is striking not only because foreign direct $R \& D$ investment constitutes a significant proportion (75\%) of total FDI in UK manufacturing, but also because, as suggested by Blonigen (1997), it may respond differently to changes in the exchange rate due to its high degree of asset specificity. By distinguishing between low and high R\&D FDI, our modelling approach allows us to test this hypothesis and more accurately establish the validity of competing theoretical frameworks. Third, unlike most previous studies, which simply assumed weak exogeneity of all the regressors, we explicitly address the endogeneity problem by re-estimating the model using the Arellano and Bond (1991) one step generalised methods of moments (GMM) procedure while including lagged values of the time-varying regressors as additional independent variables. Finally, since there is no reason to assume that the magnitude of the response of FDI to changes in the exchange rate is the same following an increase or decrease in the value of sterling, we explicitly test for asymmetries in the investment response coefficients across appreciation and depreciation intervals. 
The remainder of the paper is set out as follows. Section 2 reviews the theoretical and empirical literature linking FDI to the level and volatility of the exchange rate. In section 3 the model and the data are described. Section 4 presents and discusses the empirical results while the last section draws some conclusions and points to profitable avenues for future research.

\section{The link between FDI and exchange rates}

Up until the early 1990s, the conventional view proclaimed the impossibility of any link between exchange rates and FDI. The underlying argument (Mundell, 1968) is that changes in the exchange rate cannot provide systematic cost-of-capital advantages to either foreign or domestic firms since, under perfect capital mobility, risk-adjusted expected returns on all international assets will be equalised. That is, as a currency depreciates, since the returns on that currency assets will also decline, the relative valuation of domestic versus foreign firms for those assets will remain unchanged.

Despite its logical appeal, the argument for the theoretical independence from the exchange rate of FDI decisions was challenged by Caves (1988) who examined inward investment flows into the US from several countries and found that the strength of a country's currency relative to the US dollar was an important explanatory variable for that country's direct investment into the US. To rationalise the apparent contradiction between traditional theory and evidence, various hypotheses have emerged to shed light on the relationship between FDI and both the level and volatility of the exchange rate.

The first model is due to Froot and Stein (1991). They examine the connection between exchange rates, wealth positions of firms and FDI, when 
globally integrated capital markets are subject to informational imperfections. Their model considers US target firms sold at auction to the highest bidder. Due to monitoring costs, informational asymmetries about an asset's payoffs cause external financing to be more expensive than internal financing. As a result, the more net wealth the bidder can bring to such an 'information-intensive' investment, the lower will be his total cost of capital. As explained by Froot and Stein (1991, p.1194) "to the extent that foreigners hold more of their wealth in non-dollar denominated form, a depreciation of the dollar increases the relative wealth position of foreigners, and hence lowers their relative cost of capital", so that, ceteris paribus, more foreign investors win auctions. Empirically, Froot and Stein found that when regressing inflows of FDI into the US against the exchange rate, for the period 1973 to 1988, FDI was negatively correlated to the value of the US dollar.

Froot and Stein's results, however, have not received unanimous support. Dewenter (1995) used transaction-specific data on foreign acquisitions of US target firms completed during 1975-1989 to examine the relationship between the value of the dollar and both the flow and prices of cross-border acquisitions. Dewenter's study concluded that, after controlling for overall investment levels and relative corporate wealth, "the measure of foreign investment relative to domestic investment shows no significant exchange rate sensitivity" (p.415), a finding which casts doubt on Froot and Stein's hypothesis. Stevens (1998) specifically questioned the structural stability of the estimates obtained by Froot and Stein by showing that their results were not robust for sub-samples within their original sample, and that when the latter was extended to 1991, the exchange rate coefficient turned out to be insignificant.

An alternative explanation for the link between the exchange rate and FDI has been advanced by Blonigen (1997). He postulated that exchange rate movements 
affect FDI because acquisitions involve firm-specific assets that can generate returns in currencies other than that used for purchase, yet do not involve a currency transaction as does the initial purchase of the asset. The model considers a firm that intends to purchase knowledge-rich foreign assets in the foreign currency, and by leveraging this knowledge in its home market expects to generate returns in its own currency as a result of this acquisition. Under this scenario, given that the foreign firm's costs and returns are in different currencies, a depreciation of the foreign currency would increase the firm's reservation bid for the knowledge-rich asset (relative to domestic firms' reservation bid), thus increasing its likelihood to win the auction. Blonigen tested his model using data of Japanese acquisitions across US industries for the 1975-1992 period. He found that real dollar depreciations lead to substantial increases in acquisition FDI in industries that more likely have firm-specific assets, namely, manufacturing industries with high R\&D.

Contrary to the models by Froot and Stein (1991) and Blonigen (1997) both of which, albeit through different channels, predict a negative relationship between the exchange rate level and inward FDI, Campa (1993) postulated a positive relationship arguing that an appreciation of the host country's currency will increase investment into the host country since the expectation of future profits is higher. Campa (1993) also estimated the effect that exchange rate volatility and industryspecific sunk costs have on entry by foreign firms. Using a measure of FDI based on the number of foreign entries in 61 US wholesale industries over the period 1981 to 1987, he found volatility to be negatively correlated with the number of events of entry, and that this effect is stronger in industries where sunk costs are relatively high. 
Other studies on the impact of exchange rate volatility on international investment flows (Cushman, 1985 and 1988; Dixit, 1989; Bailey and Tavlas, 1991; Sercu and Vanhulle, 1992; Goldberg and Kolstad, 1995; Sung and Lapan, 2000) have produced mixed results, with positive or negative effects being found depending on the assumptions employed in relation to the risk preferences of foreign investors, cost reversibilities and the timing of entry and production decisions. In summary, just like the case of the level of the exchange rate, the question of the impact of exchange rate uncertainty on FDI flows remains unresolved.

\section{Model and data}

In addition to the real exchange rate and exchange rate volatility, the literature has suggested a number of other FDI determinants. Also the impact of some of these variables is theoretically ambiguous, thus leaving to the empirical results the task of establishing the sign and significance of prevailing effects. Drawing from output and market size hypotheses, economic growth of the host country deserves a 'place of honour' in the baseline FDI equation. According to these hypotheses growth is expected to encourage greater supply of FDI since it generates an expanding market for the producer's goods. Several empirical studies find such a positive relationship, including Billington (1999) published in this journal.

The inclusion of the relative cost of labour and capital too is standard in FDI regressions since it provides a comparison of costs of production between domestic and foreign economies. The higher the cost of labour at home vs. that of the host country, the greater the incentive to invest and produce in the host country. However, it should be noted that the significance of relative labour costs is expected to be greater in the case of FDI flows from developed to developing countries, particularly 
for investments in labour-intensive industries. With respect to relative capital costs, as originally postulated by Aliber (1970), it is expected that the higher the cost of borrowing in the host country relative to that of the country of origin of the investment, the greater the ability of foreign firms to compete in the host market and thus the greater the incentive to invest there (see also Grosse and Trevino, 1996).

In his survey of the empirical literature on FDI, Chakrabarti (2001) offers valuable insights into how trade variables could pick up different effects in FDI equations, depending on the circumstances and the motivation of the investment decision. For example, while greater trade barriers could increase FDI if the investment is tariff-jumping, they may decrease FDI if the investment is meant to serve as an export platform. In this paper we have chosen to examine the impact of trade openness of the host country. Trade openness may have a positive influence on inward FDI because MNEs are attracted to open economies by virtue of their intrinsic export potential and generally more stable economic climate. Interestingly, Wheeler and Mody (1992) reported a strong positive effect of openness on FDI in manufacturing but a weak negative link in the electronic sector, suggesting that the relationship may vary across industries. Moreover, as noted by Sun et al. (2002), the degree of openness can also have a negative impact on FDI due to greater competition, making the prevailing net effect an empirical question.

The emergence of gravity models has made geographic distance a popular regressor in equations aimed at explaining the direction of both trade and FDI flows. The greater is the proximity between two countries, the more they are expected to trade. But as proximity decreases, the greater is the incentive to set up production facilities in the target market since the transportation costs to be incurred via exporting would be higher (Krugman, 1991). On the other hand, geographic distance 
has also been used as a proxy for informational frictions (Grosse and Trevino, 1996). According to this view, distance may have a negative effect on inward FDI because of the greater costs of obtaining information about the host country and of managing production plants located overseas.

The literature also points to psychic distance as a potential determinant of FDI (see Kogut and Singh, 1988). The concept is usually operationalised in terms of uncertainty about would-be-host markets due to differences in culture, language and levels of education. Since geographic distance may not necessarily reflect psychic distance, we control for the latter by including a dummy variable that takes the value of one if the country of origin is English speaking, and the value of zero otherwise.

Recent literature also emphasises the role of agglomeration economies (see Head et al., 1995). In order to capture agglomeration effects we include the one-year lagged FDI flows as a regressor. Following Campos and Kinoshita (2003), this choice of proxy for the geographic clustering of economic activities is justified by the fact that if the potential for positive externalities stemming from technological spillover effects enters the investors' location decision, we expect the level of FDI at period $t-1$ to be a good predictor of the level of FDI at period $t$.

We also control for the effect of stock market growth in the host economy. Stock market growth could affect FDI in a number of ways. For example, increased stock market growth could discourage inward FDI, through a higher initial cost of purchase, or could induce FDI, since higher share prices could be taken as an indication of higher profitability levels in the host market.

Drawing from the variables outlined above, our panel regression model is specified as follows (lower case letters denote the use of natural logarithms): 


$$
\begin{aligned}
\mathrm{f}_{\mathrm{it}}= & \alpha_{0}+\alpha_{1} \mathrm{f}_{\mathrm{it}-1}+\alpha_{2} \mathrm{ds}_{\mathrm{i}}+\alpha_{3} \mathrm{LANG}_{\mathrm{i}}+\alpha_{4} \mathrm{re}_{\mathrm{it}}+\alpha_{5} \mathrm{v}_{\mathrm{it}}+\alpha_{6} \dot{\mathrm{y}}_{\mathrm{t}}+\alpha_{7} \mathrm{tr}_{\mathrm{t}}+\alpha_{8}\left(\mathrm{r}^{*}-\mathrm{r}\right)_{\mathrm{it}} \\
& +\alpha_{9}\left(\mathrm{w}^{*}-\mathrm{w}\right)_{\mathrm{it}}+\alpha_{10} \dot{\mathrm{sm}}_{\mathrm{t}}+\varepsilon_{\mathrm{it}}
\end{aligned}
$$

$$
\text { for } \mathrm{i}=1, \ldots, \mathrm{n} \text { and } \mathrm{t}=1, \ldots, \mathrm{T}
$$

where $\mathrm{f}$ is net real FDI flows into the UK (from country i) divided by the domestic private fixed investment deflator $(1995=100)$. The main advantage of using net real FDI flows compared to FDI measures based on the number of acquisitions or investment announcements, is that the former also encompasses investors' retrenchment (or divestment) decisions resulting from real exchange rate movements. ds is the geographic distance (in kilometres) between the source country's capital and London, and $\mathrm{LANG}_{\mathrm{i}}$ is the language dummy variable. The variable re is the real (rather than nominal) spot exchange rate between pound sterling and the source country's currency ${ }^{2}, \mathrm{~V}$ is a volatility measure for the real exchange rate, $\dot{y}$ is UK economic growth (defined as the annual change in the log of UK per capita GDP), tr is a indicator of UK trade openness, $\left(\mathrm{r}^{*}-\mathrm{r}\right)$ and $\left(\mathrm{w}^{*}-\mathrm{w}\right)$ are real (short-term) interest rate and wage differentials, and $\dot{\mathrm{sm}}_{\mathrm{t}}$ is UK stock market growth (for a more detailed definition of the individual series and data sources see Data Appendix). It is anticipated that $\alpha_{1}>0, \alpha_{3}>0, \alpha_{6}>0, \alpha_{8}<0, \alpha_{9}>0$ while the sign of $\alpha_{2}, \alpha_{4}, \alpha_{5}, \alpha_{7}$ and $\alpha_{10}$ is theoretically ambiguous.

Equation (1) is estimated for the period 1975-2001 using, in the first instance, a fixed effects panel technique ${ }^{3}$. We use annual data on UK inward FDI flows, pooled across the USA, France, Germany, the Netherlands, Switzerland, Australia and

\footnotetext{
${ }^{2}$ Where the exchange rate is defined as the price of pounds sterling in terms of units of foreign currency.

${ }^{3}$ This allowed us to establish the presence of any country-specific effects. Variations between countries are modelled using dummies. We also estimated (1) using a random-effects technique, which treats country-specific effects as random variables. We found the results of the fixedeffects procedure to be superior in that it produced an estimated model with higher $\mathrm{R}^{2}$ and no serial correlation.
} 
Japan. All observations were available for each series and country, so we benefited from a balanced panel.

FDI flows are measured using a series for all manufacturing, and for investment flows in high and low R\&D sectors separately. High and low R\&D FDI data were calculated using the Standard Industrial Classification, 1992. Relevant industries were identified from data published in 'Research and Development in UK Businesses', Business Monitor MA14 (ONS). The high R\&D industries are chemicals, plastics and fuels, metal and mechanical products, office and IT equipment and transport equipment. The low $R \& D$ industries include food products, textile and wood, and other manufacturing. The exchange rate is defined as the price of sterling expressed in terms of foreign currency and converted into real terms using producer price indices for the UK and foreign economies. Exchange rate volatility is derived using monthly real exchange rates by means of the following $\operatorname{GARCH}(1,1)$ model $^{4}$ :

$$
\begin{array}{r}
\mathrm{re}_{\mathrm{t}}=\sum_{\mathrm{i}=1}^{\mathrm{p}} \delta_{\mathrm{i}} \mathrm{re}_{\mathrm{t}-\mathrm{i}}+\varepsilon_{\mathrm{t}} \\
\mathrm{h}_{\mathrm{t}}=\alpha_{0}+\alpha_{1} \varepsilon_{\mathrm{t}-1}^{2}+\beta_{1} \mathrm{~h}_{\mathrm{t}-1}
\end{array}
$$

Where $\mathrm{re}_{\mathrm{t}}$ is the real exchange rate and $\varepsilon_{\mathrm{t}}$ is the stochastic term. The value of $\mathrm{p}$ is set to ensure that the estimated residuals are free from serial correlation. An annual measure is constructed as the sum of the monthly values of $h_{t}$ for each year.

\section{Estimation Results}

\footnotetext{
${ }^{4}$ In searching for the optimal volatility measure, during the pre-testing phase we experimented with several ARCH, GARCH and standard deviation specifications. Using a range of model selection criteria, we found that the $\operatorname{GARCH}(1,1)$ process provided the best overall fit to the data. For a detail illustration of an analogous selection tournament among competing proxies of exchange rate volatility, see the authors' previous work on volatility and trade (De Vita and Abbott, 2004).
} 
Before proceeding with the estimation of (1) we investigated the integration properties of the series. Panel unit root tests (Im et al., 2003) were undertaken for all the time dependent variables except trade openness, stock market growth and economic growth, for which standard ADF tests were estimated.

For the panel unit root test an ADF model was constructed using the $\mathrm{T}$ observations for the $\mathrm{n}$ series relating to the individual countries:

$$
\Delta y_{i t}=a_{i 0}+a_{i 1} y_{i t-1}+a_{i 2} t+\sum_{j=1}^{p_{i}} \beta_{i j} \Delta y_{i t-j}+\varepsilon_{i t} \quad \text { for } i=1, \ldots n
$$

(3) was estimated including just an intercept $\left(\mathrm{a}_{\mathrm{i} 0}\right)$ and an intercept and deterministic trend $(\mathrm{t})$. The $\mathrm{t}$-statistic was used to test the null hypothesis $\mathrm{a}_{\mathrm{i} 1}=0$. The panel unit root test is the average of the individual $\mathrm{t}$-statistics from the $\mathrm{n}$ series:

$$
\overline{\mathrm{t}}=(1 / \mathrm{n}) \sum_{\mathrm{i}=1}^{\mathrm{n}} \mathrm{t}_{\mathrm{i}} \quad \text { for } \mathrm{i}=1, \ldots, \mathrm{n}
$$

The $\overline{\mathrm{t}}$-statistic is compared to the critical values generated by Im et al. (2003), for different values of $\mathrm{n}$ and T. The results are shown in Table 1. Hypothesis testing for $\mathrm{H}_{0}: \mathrm{a}_{\mathrm{i} 2}=0$ suggested that, in nearly all cases, the deterministic trend was not significant. Therefore, while we present test statistics for intercept and intercept and trend cases, the most relevant statistics are the intercept only values. Each of the $\overline{\mathrm{t}}-$ statistics exceeds the critical values at the $5 \%$ level, thus suggesting that at least one of the $\alpha_{i}$ estimates differs from zero. For those series that do not vary across source economies, namely $\dot{\mathrm{y}}_{\mathrm{t}}, \operatorname{tr}_{\mathrm{t}}$ and $\dot{\mathrm{sm}}_{\mathrm{t}}$, conventional ADF tests suggest that the level of each series is stationary.

Table 1 near here

The results from estimating (1) for inward FDI flows are reported in Table 2. Separate estimates are produced for total manufacturing, high and low R\&D sectors. 
The Wald test for exclusion restrictions on the coefficients of the country-specific dummies is highly statistically significant in each case, thereby validating our use of panel estimation techniques over pooled OLS estimation. Diagnostic tests and a high $\mathrm{R}^{2}$ denote an adequate model specification. To check for possible correlation patterns among the regressors, a correlation matrix was estimated (Table 3). Despite the inevitable correlation between the two exchange rate measures, none of the other coefficients have values in excess of 0.6 , thus suggesting an absence of any serious multicollinearity problem.

\section{Tables 2 and 3 near here}

Given the purpose of this study, our interest inevitably centres upon the impact of the exchange rate variables. The real exchange rate is found to have a positive and significant influence for all three cases. This suggests that a rise in the cost of pounds sterling in foreign currency terms increases the level of inward FDI flows. At the same time the foreign currency value of the returns from this investment will increase. For total manufacturing and the high R\&D sectors, a $10 \%$ appreciation of sterling leads, on average, to a $2.48 \%$ and $2.52 \%$ increase in inward FDI activity respectively, whereas for the low $\mathrm{R} \& \mathrm{D}$ sectors a $3.47 \%$ increase is predicted. This result is at odds with the prediction of the models by Froot and Stein (1991) and Blonigen (1997) but is broadly consistent with the findings of Campa (1993) for the USA. The only study that has previously looked at the determinants of UK inward FDI (Pain, 1993) found a negative real exchange rate effect. Given that differences in the definition of the variables, methodology employed and sample period used make a direct comparison with previous findings difficult, we tried to rationalise the puzzling finding of a positive relationship between FDI inflows and the real exchange rate by means of a detailed analysis of the stylized facts discernible from 
the trends in the raw data ${ }^{5}$. However, this exercise did not prove particularly illuminative. Moreover, one may only speculate as to why the exchange rate effect is found to be most pronounced for investments in low $R \& D$ sectors. The only plausible explanation might be that in low $\mathrm{R} \& \mathrm{D}$ sectors, where profit margins tend to be lower and there is greater cost-based competitive rivalry (Anderton and Brenton, 1998), the expectation of higher future profits stemming from an appreciation of the host country's currency constitutes an even stronger motivation for FDI.

With respect to exchange rate volatility, a significant and negative effect is found in all three cases, though it appears to be particularly pronounced for investments in the high $\mathrm{R} \& \mathrm{D}$ sectors where non-recoverable entry, maintenance and exit costs are likely to be greater. We interpret this result as one lending further support to the theoretical argument and findings presented by Campa (1993). However, while the FDI measure adopted by Campa was exclusively based on events of foreign entry (into the US), by analysing FDI flows, our evidence extends the validity of the argument to dis-investment (exit) activity resulting from increased exchange rate volatility.

In terms of the other regressors, as expected, the agglomeration economies coefficients are found to be positive and significant for FDI flows in total manufacturing and in high $\mathrm{R} \& \mathrm{D}$ sectors. This result is consistent with evidence found for other countries such as Italy (see Bronzini, 2004) and the US (see Head et al., 1995). The coefficient is insignificant for the case of FDI in low R\&D sectors. The intuition behind this result is that opportunities to access unique resources and

${ }^{5}$ From 1975 to 2001 sterling appreciated on average by $46.3 \%$ in real terms, with a $16.8 \%$ appreciation between 1990 and 2001 and a 3.8\% appreciation since 1995. During the same periods inward FDI increased significantly: 829\% from 1975 to 2001, 288\% from 1990 to 2001, and $119 \%$ from 1995 to 2001 . The largest rises during the boom period of the 1990 s took place in 
capture externalities arising from close proximity to technological leaders are fewer in industries characterised by low R\&D expenditure (see Driffield and Love, 2003).

Geographic distance appears to play a positive and significant role in the determination of UK inward FDI flows. On average, those firms located in countries farthest away from the UK tend to invest more heavily. Not surprisingly the magnitude of this effect is greatest for the low $R \& D$ sectors, which are characterized by more bulky goods likely to increase transportation costs. As argued by Görg and Strobl (2000), sectors identified as high-tech, are sectors which produce goods with a high value-to-weight ratio and the production of those 'weightless goods' is more easily transferable internationally than the production of bulky, low-tech goods. The language coefficient is also positive and significant, confirming that cultural proximity induces higher FDI inflows. Görg and Wakelin (2002) report a similar effect of the language variable on US FDI.

Consistent with previous empirical findings (Culem, 1988; Billington, 1999), the estimates for economic growth are found to be significant and positive, though in each of the cases considered the size of the effect is rather small. Trade openness and real wage differentials are found to have no significant impact on FDI flows. Wage rate differentials are not particularly strong across the countries included in our sample. While they may be important for FDI in developing countries, they are less relevant in the case of more advanced industrialised economies.

In line with prior expectations, the real interest rate differential coefficient is found to be negative and significant for total FDI and FDI in the high R\&D sectors, suggesting that a higher real cost of capital in the source economy relative to the UK induces a lower level of inward investment. This result is consistent with the fact

low R\&D sectors (from 1995 to 2001 high R\&D FDI increased by 43\%, whereas low R\&D FDI 
that, being a measure of capital flows, FDI is mostly financed from funds obtained in the home country. The higher the cost of borrowing at home relative to that in the UK, the lesser the ability of foreign firms to gain a cost advantage over UK rivals (which have access to cheaper finance) and exploit that advantage to pursue FDI in the UK. The insignificance of the cost of capital coefficient in low R\&D sectors may be due to the fact that investments in these sectors require, on average, a lower degree of external financing. Finally, stock market growth is only significant in one case, where it is found to have a positive influence on FDI in the high R\&D sectors.

In examining the impact of exchange rate levels on sectoral investments in the US for the 1970-1989 period, Goldberg (1993) found that the relationship between exchange rate movements and FDI had changed over time. In the light of Goldberg's (1993) results, and as a test for robustness, we, therefore, also checked for possible shifts in the size and significance of the parameters across consecutive sub-periods of our original sample (1975-1986 vs 1987-2001) ${ }^{6}$. Our results, not reported here to conserve space, confirm the temporal stability of the estimated coefficients reported in Table 2, thereby indicating that the sign and significance of the relationships identified have not changed over time. ${ }^{7}$

Still intrigued by the finding of a positive coefficient for the level of the real exchange rate and in order to ensure the reliability and consistency of our estimates, at this stage, we decided to subject our results to further empirical scrutiny with respect to two potential sources of bias. The first one stems from the fact that under fixed effects estimation, the consistency of the coefficient of the lagged dependent

\footnotetext{
increased by $177 \%$ ) for which a larger real exchange rate elasticity is found.

${ }^{6}$ The decision to split the sample at 1987 was motivated by the visual inspection of Fig.1, which suggested a possible structural break in the FDI series at that time.

${ }^{7}$ Using dummies for each time period multiplied by the real exchange rate, we also tested for the joint significance of the dummy coefficients. The insignificance of the Wald test for exclusion
} 
variable is not ensured (see, for example, Judson and Owen, 1999, and Layard and Nickell, 1986). The second potential problem relates to the assumption of weak exogeneity of the regressors included in the estimation of a reduced form FDI equation. Since most of the regressors included in (1) are likely to be endogenous, this assumption is clearly untenable. To obtain consistent estimates, therefore, we reestimated the model using the generalised methods of moments (GMM) by Arellano and Bond $(1991)^{8}$ while also controlling for endogeneity problems by using lagged values of the time-varying regressors as additional independent variables.

As part of this re-estimation exercise, we also tested for asymmetries in the investment response coefficients across appreciation and depreciation intervals. Indeed, while the results reported in Table 2 suggest that the real exchange rate has a significant positive impact on FDI flows into the UK, it may be possible that, if confirmed, this effect is not symmetrical. That is, the size of the increase in FDI due to a given appreciation of sterling may be different to the decline in FDI due to an equivalent depreciation of the UK pound. To test this hypothesis, an intercept dummy variable (dumre), which takes a value of one if the value of sterling has appreciated since the previous year, and the value of zero otherwise, was created. In addition to testing the dummy for appreciation, the interaction for the level of the exchange rate and the dummy was modelled using dumrexre. While the former parameter is meant to capture the asymmetry, the latter should be informative as to

restrictions confirmed that the exchange rate effect was relatively constant over the sample period.

${ }^{8}$ To implement the Arellano-Bond estimator we took the first difference of all of the variables in (1), dropping distance and common language since they are time-invariant. Since $\Delta \varepsilon_{\mathrm{it}}$ and $\Delta \mathrm{Y}_{\mathrm{it}-1}$ are correlated, we used lagged levels as instruments for the dependent variable and the regressors and then estimated by GMM. The validity of the instruments was assessed using the Sargan's test for over-identifying restrictions (Sargan, 1958). The unbiasedness of the estimates was addressed by testing for serial correlation up to $2^{\text {nd }}$ order. 
whether appreciations from a high level of the exchange rate have less of an impact than those starting from a lower level.

\section{Table 4 near here}

The results from this exercise are found in Table 4, which compares fixed effects estimates of the revised model with those obtained from the GMM procedure. Although we view the latter as the most appropriate set of results (the Sargan test indicates that we cannot reject the validity of the over-identifying restrictions and the AR test confirms the absence of serial correlation up to $2^{\text {nd }}$ order), by and large the GMM estimates corroborate those obtained from fixed effects estimation. The most notable exception relates to the exchange rate variable $\mathrm{r}_{\mathrm{t}}$, the impact of which is found to be statistically insignificant for total FDI as well as high and low R\&D sectors. Contrary to the results reported in Table 2, the corrective estimation procedure also reveals a significant negative coefficient for trade openness, of large magnitude. With respect to potential asymmetric effects, the GMM estimation results show that each of the dummy coefficients (dumre and dumrexre) is not statistically significant.

\section{Conclusions}

This paper aimed to establish the impact of the level and volatility of the exchange rate on UK inward FDI during the period 1975-2001. In addition to exchange rate variables, our pooled regression model allowed us to control for several FDI determinants identified in previous literature, including features of the country of origin and the sector of destination of the investment.

We found strong evidence of a negative and significant relationship between real exchange rate volatility and FDI inflows. These results prove robust to tests for 
parameter stability, to tests for asymmetries in the investment response coefficients across appreciation and depreciation intervals and to re-estimation by the ArellanoBond GMM corrective procedure. Our results also show that, after controlling for endogeneity problems, the real exchange rate appears to have no statistically significant influence on UK inward FDI.

Notwithstanding the value of the findings uncovered by this study, three caveats should be borne in mind when interpreting our results. First, despite our efforts to control for all the main variables identified in the literature as potential determinants of FDI, it should be acknowledged that our results may still be driven by some omitted factor that is correlated with the exchange rate. Second, we have only examined the impact of exchange rates on inward FDI to the UK. Yet, as suggested by Görg and Wakelin (2002), it may be useful to consider both inward and outward investment, even simply as a test for consistency. Third, although our best proxy for exchange rate uncertainty models expected volatility in a series conditional on past behaviour, it should be recognised that, as with any other volatility measure, our proxy is based on assumptions of how memory and foresight inform agents' expectations. Whether survey data on the investors' actual forecasts would alter the estimated measure of exchange rate volatility is yet to be established. These caveats provide a stimulating agenda for further analysis.

\section{References}

Aliber (1970) A theory of foreign direct investment, in C. Kindleberger (ed.). The international corporation. MIT Press, Cambridge, Mass.

Amuedo-Dorantes, C. and Pozo, S. (2001) Foreign exchange rates and foreign direct investment in the United States, The International Trade Journal, 15, 323-343. 
Anderton, B. and Brenton, D. (1998) The dollar, trade, technology and inequality in the USA, National Institute Economic Review, 166, 11-13.

Arellano, M. and Bond, S. (1991) Some tests of specification for panel data: Monte Carlo evidence and an application to employment equation, Review of Economic Studies, 58, 277-297.

Bailey, M. J. and Tavlas, G. S. (1991) Exchange rate variability and direct investment, The Annals, American Academy of Political and Social Science, 516, 106-116.

Billington, N. (1999) The location of foreign direct investment: An empirical analysis, Applied Economics, 31, 65-76.

Blonigen, B. (1997) Firm-specific assets and the link between exchange rates and foreign direct investment, American Economic Review, 87, 447-465.

Bronzini, R. (2004) Foreign direct investment and agglomeration: Evidence from Italy”, Temi di Discussione, Banca D’Italia, No.526, December 2004.

Campa, J.M. (1993) Entry by foreign firms in the United States under exchange rate uncertainty, Review of Economics and Statistics, 75, 614-622.

Campos, N.F. and Kinoshita, Y. (2003) Where does FDI goes where it goes? New evidence from transition economies, IMF Working Paper No.03/228.

Caves, R.E. (1988) Exchange rate movements and foreign direct investment in the United States, Harvard Institute of Economic Research, May.

Chakrabarti, A. (2001) The determinants of Foreign Direct Investment: Sensitivity Analyses of cross-country regressions, Kyklos, 54, 1, 89-114. 
Chakrabarti, R. and Scholnick, B. (2002) Exchange rate expectations and FDI flows, Weltwirtschafliches Archiv, 138, 1, 1-21.

Culem, C. (1988) The location determinants of direct investments among industrialized countries, European Economic Review, 32, 885-904.

Cushman, D.O. (1985) Real exchange rate risk, expectations, and the level of foreign direct investment, Review of Economics and Statistics, 67, 297-308.

Cushman, D.O. (1988) Exchange-rate uncertainty and foreign investment in the United States, Weltwirtschafliches Archiv, 124, 2, 322-335.

De Vita, G. and Abbott, A. (2004) The impact of exchange rate volatility on UK exports to EU member countries, Scottish Journal of Political Economy, 51, 62-81.

Dewenter, K.L. (1995) Do exchange rates drive foreign direct investment?, Journal of Business, 68, 405-433.

Dixit, A. (1989) Entry and exit decisions under uncertainty, Journal of Political Economy, 97, 3, 620-638.

Driffield, N. and Love, J. (2003) Foreign direct investment, technology sourcing and reverse spillovers, the Manchester School, 71, 6, 659-672.

Froot, K. and Stein, J. (1991) Exchange rates and foreign direct investment: An imperfect capital markets approach, Quarterly Journal of Economics, 106, 11911217.

Goldberg, L.S. (1993) Exchange rates and investment in United States industry, Review of Economics and Statistics, 75, 575-588.

Goldberg, L.S. and Kolstad, C. (1995) Foreign direct investment, exchange rate variability and demand uncertainty, International Economic Review, 36, 855-873. 
Görg, H. and Strobl, E. (2000) Multinational companies, technology spillovers and Firm Survival: Evidence from Irish Manufacturing, Centre for Research on Globalisation and Labour Markets, Research Paper 2000/12.

Görg H. and Wakelin, K. (2002) The impact of exchange rate volatility on US direct investment, The Manchester School, 70, 380-397.

Grosse, R. and Trevino, L.J. (1996) Foreign direct investment in the United States: An analysis by country of origin, Journal of International Business Studies, 27, 139156.

Head, K., Ries, J. and Swenson, D. (1995) Agglomeration benefits and location choice: Evidence from Japanese manufacturing investments in the United States, Journal of International Economics, 38, 223-248.

Im, K. S., Pesaran, H. M. and Shin, Y. (2003) Testing for unit roots in heterogenous panels, Journal of Econometrics, 115, 53-74.

Judson, R.A. and Owen, A.L. (1999) Estimating dynamic panel data models: A guide for macroeconomists, Economics Letters, 65, 1, 9-15.

Kogut, B. and Singh, H. (1988) The effect of national culture on the choice of entry mode, Journal of International Business Studies, 19, 411-432.

Krugman, P. (1991) Increasing returns and economic geography, Journal of Political Economy, 99, 3, 483-499.

Layard, R. and Nickell, S. (1986) Unemployment in Britain, Economica, 53, 51215169 .

Mundell, R. A. (1968) International Economics, New York, Macmillan. 
Pain, N. (1993) An econometric analysis of FDI in the UK, Scottish Journal of Political Economy, 40, 1-23.

Sargan, J. D. (1958) The estimation of economic relationships using instrumental variables, Econometrica, 26, 393-415.

Sercu, P. and Vanhulle, C. (1992) Exchange rate volatility, international trade and the value of exporting firms, Journal of Banking and Finance, 16, 155-182.

Stevens, G.V.G. (1998) Exchange rates and foreign direct investments: A note, Journal of Policy Modeling, 20, 393-401.

Sun, Q., Tong, W. and Yu, Q. (2002) Determinants of foreign direct investment across China, Journal of International Money and Finance, 21, 79-113.

Sung, H. and Lapan, H.E. (2000) Strategic foreign investment and exchange rate uncertainty, International Economic Review, 41, 411-423.

Wheeler, D. and Mody, A. (1992) International investment location decisions: The case for U.S. firms, Journal of International Economics, 33, 57-76. 
Figure 1: Inward FDI flows from seven major source countries

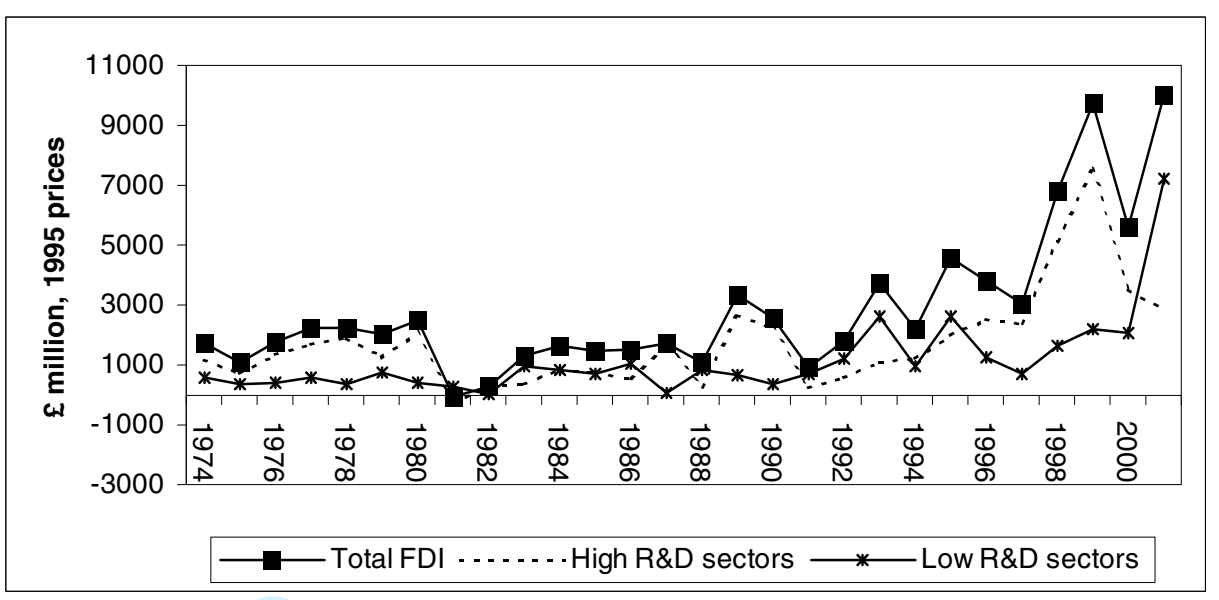

Figure 2: Inward FDI flows and trade-weighted effective exchange rate index for the seven major source countries

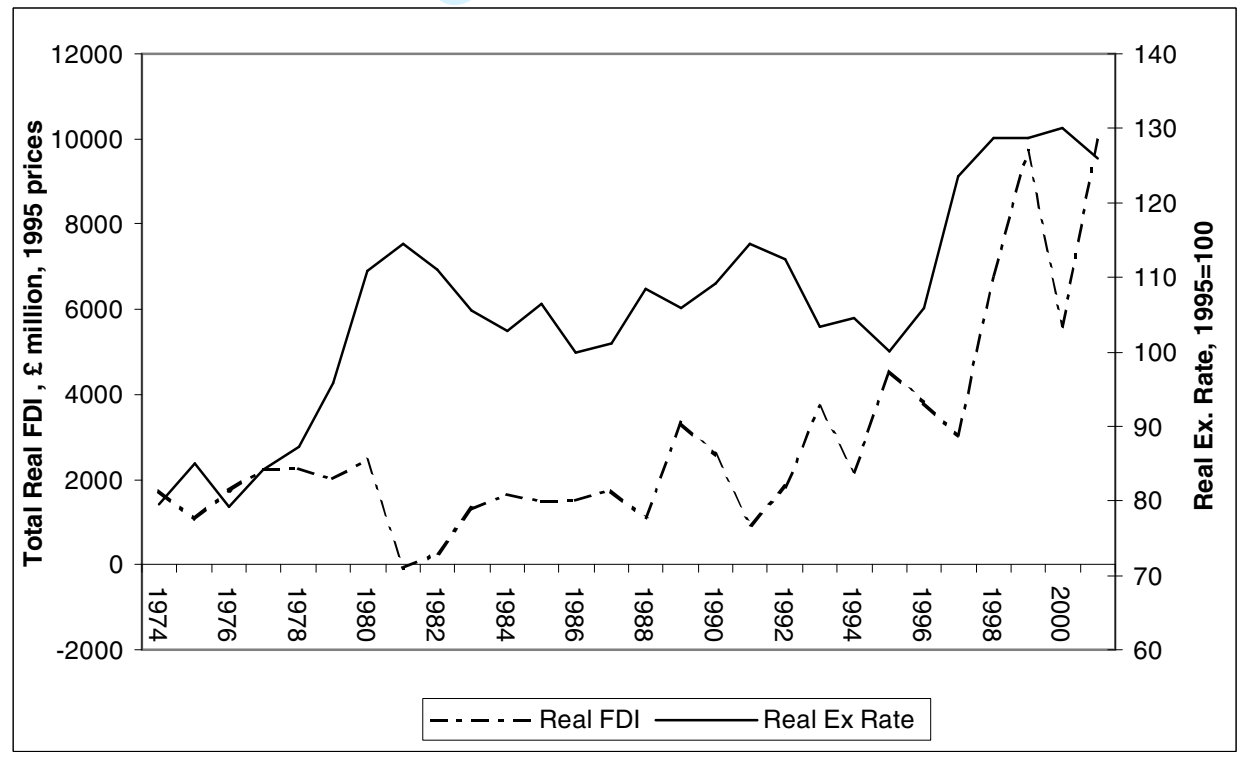


Table 1: Unit Root Tests

\section{$\bar{t}$ statistics}

\begin{tabular}{|c|c|c|c|c|c|c|c|c|}
\hline \multicolumn{3}{|c|}{ f: Total FDI } & \multicolumn{3}{|c|}{ f: high R\&D sectors } & \multicolumn{3}{|c|}{ f: low R\&D sectors } \\
\hline $\begin{array}{c}\text { Intercept } \\
\text { only }\end{array}$ & \multicolumn{2}{|c|}{$\begin{array}{c}\text { Intercept and } \\
\text { trend }\end{array}$} & $\begin{array}{l}\text { Intercept } \\
\text { only }\end{array}$ & \multicolumn{2}{|c|}{$\begin{array}{c}\text { Intercept and } \\
\text { trend }\end{array}$} & \multicolumn{2}{|c|}{$\begin{array}{c}\text { Intercept } \\
\text { only }\end{array}$} & $\begin{array}{c}\text { Intercept and } \\
\text { trend }\end{array}$ \\
\hline-4.235 & \multicolumn{2}{|c|}{-4.376} & -7.296 & \multicolumn{2}{|c|}{-7.912} & \multicolumn{2}{|c|}{-8.002} & -8.759 \\
\hline \multicolumn{2}{|c|}{$\operatorname{Re}$} & \multicolumn{2}{|r|}{$\mathbf{v}$} & \multicolumn{3}{|c|}{$\left(\mathbf{r}^{*}-\mathbf{r}\right)$} & \multicolumn{2}{|c|}{$\left(w^{*}-w\right)$} \\
\hline $\begin{array}{c}\text { Intercept } \\
\text { only }\end{array}$ & $\begin{array}{l}\text { Intercept } \\
\text { and } \\
\text { trend }\end{array}$ & $\begin{array}{c}\text { Intercept } \\
\text { only }\end{array}$ & $\begin{array}{l}\text { Intercept } \\
\text { and } \\
\text { trend }\end{array}$ & $\begin{array}{c}\text { Intercept } \\
\text { only }\end{array}$ & \multicolumn{2}{|c|}{$\begin{array}{l}\text { Intercept } \\
\text { and } \\
\text { trend }\end{array}$} & $\begin{array}{c}\text { Intercept } \\
\text { only }\end{array}$ & $\begin{array}{l}\text { Intercept } \\
\text { and trend }\end{array}$ \\
\hline-2.103 & -2.847 & -4.237 & -4.376 & -4.069 & \multicolumn{2}{|c|}{-4.2542} & -2.862 & -2.945 \\
\hline \\
\hline \multicolumn{9}{|c|}{ ADF statistics } \\
\hline \multicolumn{3}{|c|}{$\dot{\mathbf{y}}$} & \multicolumn{3}{|c|}{ tr } & \multicolumn{3}{|c|}{$\dot{\mathbf{s m}}$} \\
\hline $\begin{array}{l}\text { Intercept } \\
\text { only }\end{array}$ & \multicolumn{2}{|c|}{$\begin{array}{c}\text { Intercept and } \\
\text { trend }\end{array}$} & $\begin{array}{l}\text { Intercept } \\
\text { only }\end{array}$ & \multicolumn{2}{|c|}{$\begin{array}{l}\text { Intercept and } \\
\text { trend }\end{array}$} & \multicolumn{2}{|c|}{$\begin{array}{c}\text { Intercept } \\
\text { only }\end{array}$} & $\begin{array}{l}\text { Intercept and } \\
\text { trend }\end{array}$ \\
\hline-4.067 & \multicolumn{2}{|c|}{-2.945} & -3.364 & -3.078 & & & 739 & -4.769 \\
\hline
\end{tabular}

Notes: The $5 \%$ and $10 \%$ critical values for the $\overline{\mathbf{t}}$ statistics are -2.07 and -1.95 respectively when including only an intercept in (2) and -2.69 and -2.57 when using both an intercept and trend term (Im et al., 2003). For the ADF tests of the $\dot{\mathbf{y}}, \mathbf{\text { sm }}$ and tr series, the $5 \%$ and $10 \%$ critical values are -2.980 and -2.629 using an intercept only and -3.594 and -3.232 for the intercept and trend case. 
Table 2: FDI flows into UK manufacturing sector, 1975-2001.

\begin{tabular}{|c|c|c|c|}
\hline Variable & Total FDI & High R\&D sectors & Low R\&D sectors \\
\hline $\mathbf{f}_{\mathbf{t}-\mathbf{1}}$ & 0.403 & 0.469 & -0.243 \\
& $(3.09)^{\mathrm{a}}$ & $(6.40)^{\mathrm{a}}$ & $(-1.00)$ \\
\hline $\mathbf{d s}$ & 0.399 & 0.348 & 0.669 \\
& $(3.35)^{\mathrm{a}}$ & $(3.92)^{\mathrm{a}}$ & $(3.65)^{\mathrm{a}}$ \\
\hline LANG & 0.850 & 0.349 & 1.711 \\
& $(3.55)^{\mathrm{a}}$ & $(1.57)$ & $(2.67)^{\mathrm{a}}$ \\
\hline $\mathbf{r e}$ & 0.248 & 0.252 & 0.328 \\
& $(2.80)^{\mathrm{a}}$ & $(1.67)^{\mathrm{b}}$ & $(2.17)^{\mathrm{a}}$ \\
\hline $\mathbf{v}$ & -0.213 & -0.280 & -0.231 \\
& $(-2.46)^{\mathrm{a}}$ & $(-1.62)^{\mathrm{b}}$ & $(-2.03)^{\mathrm{a}}$ \\
\hline$\dot{\mathbf{y}}$ & 0.018 & 0.027 & 0.029 \\
& $(2.45)^{\mathrm{a}}$ & $(1.76)^{\mathrm{b}}$ & $(2.24)^{\mathrm{a}}$ \\
\hline $\mathbf{t r}$ & 0.067 & 0.213 & -0.276 \\
& $(0.38)$ & $(1.52)$ & $(-1.13)$ \\
\hline$\left(\mathbf{r}^{*}-\mathbf{r}\right)$ & -0.014 & -0.0073 & -0.00061 \\
& $(-2.64)^{\mathrm{a}}$ & $(-2.23)^{\mathrm{a}}$ & $(-0.042)$ \\
\hline$\left(\mathbf{w}^{*}-\mathbf{w}\right)$ & 0.017 & -0.037 & 0.107 \\
& $(0.55)$ & $(-1.09)$ & $(0.92)$ \\
\hline $\mathbf{0}$ & 0.052 & 0.141 & 0.099 \\
& $(0.71)$ & $(2.01)^{\mathrm{a}}$ & $(0.687)$ \\
\hline $\mathbf{R}^{2}$ & 0.884 & 0.914 & 0.685 \\
\hline SC: AR(1) & -1.333 & -0.869 & 0.718 \\
\hline SC: AR(4) & 0.283 & -1.307 & -1.532 \\
\hline Wald-test: $\chi_{7}^{2}$ & $16640^{\mathrm{a}}$ & $98260^{\mathrm{a}}$ & $9715^{\mathrm{a}}$ \\
\hline Nat & & & \\
\hline
\end{tabular}

Notes: t-ratios in parentheses, calculated from robust standard errors. SC:AR(1) and SC:AR(2) are tests for serial correlation up to $1^{\text {st }}$ and $2^{\text {nd }}$ order. The labels "a" and "b" denote significance at the $5 \%$ and $10 \%$ level, respectively. Wald test included for the significance of the country-pair fixed effects.

Table 3: Matrix of estimated correlation coefficients

\begin{tabular}{|c|c|c|c|c|c|c|c|c|c|}
\hline & $\mathbf{d s}$ & $\mathbf{L A N G}$ & $\mathbf{R e}$ & $\mathbf{v}$ & $\dot{\mathbf{y}}$ & $\mathbf{t r}$ & $\left(\mathbf{r}^{*}-\mathbf{r}\right)$ & $\begin{array}{c}\left(\mathbf{w}^{*}-\right. \\
\mathbf{w})\end{array}$ & $\mathbf{s m}$ \\
\hline $\mathbf{d s}$ & 1.00 & 0.715 & 0.249 & 0.308 & 0 & 0 & -0.036 & 0.183 & 0 \\
\hline LANG & & 1.00 & -0.421 & -0.374 & 0 & 0 & -0.129 & 0.594 & 0 \\
\hline $\mathbf{r e}$ & & & 1.00 & 0.992 & -0.012 & 0.002 & 0.113 & -0.556 & -0.034 \\
\hline $\mathbf{v}$ & & & & 1.00 & -0.005 & 0.011 & 0.116 & -0.526 & -0.008 \\
\hline$\dot{\mathbf{y}}$ & & & & & 1.00 & -0.020 & -0.015 & 0.139 & 0.088 \\
\hline $\mathbf{t r}$ & & & & & & 1.00 & 0.135 & -0.012 & 0.240 \\
\hline$\left(\mathbf{r}^{*}-\mathbf{r}\right)$ & & & & & & & 1.00 & -0.073 & 0.147 \\
\hline$\left(\mathbf{w}^{*}-\mathbf{w}\right)$ & & & & & & & & 1.00 & 0.046 \\
\hline $\mathbf{\text { sm }}$ & & & & & & & & & 1.00 \\
\hline
\end{tabular}


Table 4: Re-estimation controlling for endogeneity and asymmetric effects

\begin{tabular}{|c|c|c|c|c|c|c|}
\hline \multirow[t]{2}{*}{ Variable } & \multicolumn{2}{|c|}{ Total FDI } & \multicolumn{2}{|c|}{ High R\&D sectors } & \multicolumn{2}{|c|}{ Low R\&D sectors } \\
\hline & $\begin{array}{c}\text { Fixed } \\
\text { Effects }\end{array}$ & GMM & $\begin{array}{c}\text { Fixed } \\
\text { Effects }\end{array}$ & GMM & $\begin{array}{c}\text { Fixed } \\
\text { Effects }\end{array}$ & GMM \\
\hline constant & & $\begin{array}{c}-0.00003 \\
(-0.007)\end{array}$ & & $\begin{array}{l}0.006 \\
(1.03)\end{array}$ & & $\begin{array}{l}0.021^{\mathrm{a}} \\
(1.94)\end{array}$ \\
\hline $\mathbf{f}_{\mathrm{t}-1}$ & $\begin{array}{c}0.398 \\
(3.05)^{\mathrm{a}}\end{array}$ & $\begin{array}{l}0.306^{\mathrm{a}} \\
(3.12) \\
\end{array}$ & $\begin{array}{c}0.467 \\
(6.33)^{\mathrm{a}} \\
\end{array}$ & $\begin{array}{l}0.282^{\mathrm{a}} \\
(9.06)\end{array}$ & $\begin{array}{l}-0.247 \\
(-1.05) \\
\end{array}$ & $\begin{array}{l}-0.309 \\
(-1.45) \\
\end{array}$ \\
\hline $\mathbf{f}_{\mathrm{t}-2}$ & - & $\begin{array}{l}0.237^{\mathrm{a}} \\
(4.47)\end{array}$ & - & $\begin{array}{l}0.420 \\
(16.2)\end{array}$ & - & $\begin{array}{l}-0.029 \\
(-0.21) \\
\end{array}$ \\
\hline ds & $\begin{array}{c}0.393 \\
(3.34)^{\mathrm{a}}\end{array}$ & - & $\begin{array}{c}0.349 \\
(3.93)^{\mathrm{a}}\end{array}$ & - & $\begin{array}{c}0.638 \\
(4.02)^{\mathrm{a}}\end{array}$ & - \\
\hline LANG & $\begin{array}{c}1.023 \\
(4.25)^{\mathrm{a}} \\
\end{array}$ & - & $\begin{array}{c}0.338 \\
(2.08)^{\mathrm{a}} \\
\end{array}$ & - & $\begin{array}{c}2.213 \\
(3.67)^{\mathrm{a}} \\
\end{array}$ & - \\
\hline $\mathbf{r e}_{\mathrm{t}}$ & $\begin{array}{l}0.284^{\mathrm{a}} \\
(3.39)\end{array}$ & $\begin{array}{l}0.041 \\
(0.28)\end{array}$ & $\begin{array}{c}0.247 \\
(1.68)^{\mathrm{b}}\end{array}$ & $\begin{array}{l}-0.059 \\
(-0.34)\end{array}$ & $\begin{array}{c}0.432 \\
(2.25)^{\mathrm{a}}\end{array}$ & $\begin{array}{l}-0.990 \\
(-1.39)\end{array}$ \\
\hline $\mathbf{r e}_{\mathrm{t}-1}$ & & $\begin{array}{l}0.913^{\mathrm{a}} \\
(3.09) \\
\end{array}$ & - & $\begin{array}{l}0.406^{\mathrm{b}} \\
(1.71)\end{array}$ & - & $\begin{array}{l}1.391^{\mathrm{a}} \\
(2.01)\end{array}$ \\
\hline $\mathbf{r e}_{\mathrm{t}-2}$ & - & $\begin{array}{l}-0.548^{a} \\
(-3.13)\end{array}$ & - & $\begin{array}{l}-0.325^{b} \\
(-1.78)\end{array}$ & - & $\begin{array}{l}-0.639 \\
(-1.38)\end{array}$ \\
\hline dumre $_{t}$ & $\begin{array}{c}-0.016 \\
(-0.754) \\
\end{array}$ & $\begin{array}{l}-0.092 \\
(-1.24) \\
\end{array}$ & $\begin{array}{c}0.017 \\
(2.08)^{\mathrm{a}} \\
\end{array}$ & $\begin{array}{l}0.098 \\
(0.71) \\
\end{array}$ & $\begin{array}{l}-0.061 \\
(-0.68) \\
\end{array}$ & $\begin{array}{l}-0.217 \\
(-1.55) \\
\end{array}$ \\
\hline${\text { dumre } \times r_{t}}_{t}$ & $\begin{array}{l}-0.005 \\
(-1.18)\end{array}$ & $\begin{array}{l}-0.050 \\
(-1.44)\end{array}$ & $\begin{array}{l}-0.0083 \\
(-2.20)^{\mathrm{a}}\end{array}$ & $\begin{array}{l}-0.107 \\
(-1.60)\end{array}$ & $\begin{array}{l}-0.0072 \\
(-0.52)\end{array}$ & $\begin{array}{l}-0.002 \\
(-0.03)\end{array}$ \\
\hline $\mathbf{V}_{\mathrm{t}}$ & $\begin{array}{c}-0.212 \\
(-2.34)^{\mathrm{a}} \\
\end{array}$ & $\begin{array}{l}-0.232^{\mathrm{a}} \\
(-3.24) \\
\end{array}$ & $\begin{array}{l}-0.275 \\
(-1.59) \\
\end{array}$ & $\begin{array}{l}-0.234^{\mathrm{a}} \\
(-2.03)\end{array}$ & - & $\begin{array}{l}-0.220^{b} \\
(-1.81) \\
\end{array}$ \\
\hline $\mathbf{V}_{t-1}$ & - & $\begin{array}{l}-0.242^{b} \\
(-1.63)\end{array}$ & - & $\begin{array}{l}-0.134 \\
(-1.41) \\
\end{array}$ & $\begin{array}{l}-0.224 \\
(-1.85)^{\mathrm{b}}\end{array}$ & $\begin{array}{l}-0.121 \\
(-0.94)\end{array}$ \\
\hline $\mathbf{V}_{\mathrm{t}-2}$ & - & $\begin{array}{l}0.188 \\
(1.16)\end{array}$ & - & $\begin{array}{l}-0.008 \\
(-0.22)\end{array}$ & - & $\begin{array}{l}-0.344 \\
(-1.45)\end{array}$ \\
\hline$\dot{\mathbf{y}}_{\mathrm{t}}$ & $\begin{array}{c}0.016 \\
(2.34)^{\mathrm{a}} \\
\end{array}$ & $\begin{array}{l}0.003 \\
(0.16) \\
\end{array}$ & $\begin{array}{c}0.027 \\
(1.76)^{b}\end{array}$ & $\begin{array}{l}0.010 \\
(0.71) \\
\end{array}$ & $\begin{array}{c}0.022 \\
(1.85)^{\mathrm{b}}\end{array}$ & $\begin{array}{l}-0.049 \\
(-1.29) \\
\end{array}$ \\
\hline$\dot{y}_{t-1}$ & - & $\begin{array}{l}0.011 \\
(1.33)\end{array}$ & - & $\begin{array}{l}0.043 \\
(1.17)\end{array}$ & - & $\begin{array}{l}-0.024 \\
(-1.53)\end{array}$ \\
\hline$\dot{\mathrm{y}}_{\mathrm{t}-2}$ & - & $\begin{array}{l}0.027^{\mathrm{a}} \\
(2.32)\end{array}$ & - & $\begin{array}{l}0.003 \\
(0.17)\end{array}$ & - & $\begin{array}{l}0.027 \\
(1.03)\end{array}$ \\
\hline $\mathbf{t r}_{\mathrm{t}}$ & $\begin{array}{l}0.127 \\
(0.66)\end{array}$ & $\begin{array}{l}-0.523^{\mathrm{a}} \\
(-2.59)\end{array}$ & $\begin{array}{l}0.201 \\
(1.60)\end{array}$ & $\begin{array}{l}-0.559^{a} \\
(-2.95)\end{array}$ & $\begin{array}{l}-0.106 \\
(-0.32)\end{array}$ & $\begin{array}{l}-0.680^{\mathrm{a}} \\
(-1.97)\end{array}$ \\
\hline $\operatorname{tr}_{\mathrm{t}-1}$ & - & $\begin{array}{l}0.512^{\mathrm{a}} \\
(2.82)\end{array}$ & - & $\begin{array}{l}0.622^{\mathrm{b}} \\
(1.76)\end{array}$ & - & $\begin{array}{l}0.393 \\
(1.31)\end{array}$ \\
\hline $\operatorname{tr}_{\mathrm{t}-2}$ & - & $\begin{array}{l}-0.087 \\
(-0.44) \\
\end{array}$ & - & $\begin{array}{l}0.200^{\mathrm{b}} \\
(1.89)\end{array}$ & - & $\begin{array}{l}-0.353 \\
(-0.92) \\
\end{array}$ \\
\hline$\left(\mathbf{r}^{*}-\mathbf{r}\right)_{t}$ & $\begin{array}{l}-0.016 \\
(-3.75)^{\mathrm{a}}\end{array}$ & $\begin{array}{l}-0.014^{b} \\
(-1.87)\end{array}$ & $\begin{array}{l}-0.0078 \\
(-3.01)^{\mathrm{a}}\end{array}$ & $\begin{array}{l}-0.006 \\
(-0.79)\end{array}$ & $\begin{array}{l}-0.0068 \\
(-0.495)\end{array}$ & $\begin{array}{l}-0.017 \\
(-0.62)\end{array}$ \\
\hline$\left(\mathbf{r}^{*}-\mathbf{r}\right)_{t-1}$ & - & $\begin{array}{l}0.001 \\
(0.11)\end{array}$ & - & $\begin{array}{l}-0.004 \\
(-0.40)\end{array}$ & - & $\begin{array}{l}-0.020^{\mathrm{a}} \\
(-2.11)\end{array}$ \\
\hline$\left(\mathbf{r}^{*}-\mathbf{r}\right)_{\mathrm{t}-2}$ & - & $\begin{array}{l}-0.007 \\
(-0.49)\end{array}$ & - & $\begin{array}{l}-0.012 \\
(-0.94)\end{array}$ & - & $\begin{array}{c}0.007 \\
(0.359)\end{array}$ \\
\hline$\left(w^{*}-w\right)_{t}$ & $\begin{array}{l}0.028 \\
(1.04)\end{array}$ & $\begin{array}{l}0.098 \\
(0.91)\end{array}$ & $\begin{array}{l}-0.037 \\
(-1.04)\end{array}$ & $\begin{array}{l}-0.232 \\
(-1.16)\end{array}$ & $\begin{array}{l}0.142 \\
(1.48)\end{array}$ & $\begin{array}{c}-0.415 \\
(-0.929)\end{array}$ \\
\hline$\left(w^{*}-w\right)_{t-1}$ & - & $\begin{array}{l}0.325 \\
(1.90)\end{array}$ & - & $\begin{array}{l}0.300 \\
(1.38)\end{array}$ & - & $\begin{array}{l}0.930^{\mathrm{a}} \\
(2.06)\end{array}$ \\
\hline$\left(w^{*}-w\right)_{t-2}$ & - & $\begin{array}{l}-0.368 \\
(-2.54)\end{array}$ & - & $\begin{array}{l}-0.186 \\
(-1.18)\end{array}$ & - & $\begin{array}{l}-0.682^{\mathrm{b}} \\
(-1.93)\end{array}$ \\
\hline
\end{tabular}




\begin{tabular}{|c|c|c|c|c|c|c|}
\hline$\dot{s}_{t}$ & $\begin{array}{c}0.044 \\
(0.597)\end{array}$ & $\begin{array}{l}0.102 \\
(0.72)\end{array}$ & $\begin{array}{c}0.140 \\
(1.93)^{\mathrm{a}}\end{array}$ & $\begin{array}{l}0.231^{b} \\
(1.91)\end{array}$ & $\begin{array}{c}0.083 \\
(0.528)\end{array}$ & $\begin{array}{l}0.223^{\mathrm{a}} \\
(2.59)\end{array}$ \\
\hline$\dot{\mathbf{s m}_{t-1}}$ & - & $\begin{array}{l}-0.043 \\
(-0.49)\end{array}$ & - & $\begin{array}{l}0.057 \\
(1.05)\end{array}$ & - & $\begin{array}{l}0.179 \\
(1.31)\end{array}$ \\
\hline$\dot{\mathbf{s m}_{t-2}}$ & - & $\begin{array}{l}-0.014 \\
(-0.67)\end{array}$ & - & $\begin{array}{l}-0.052^{b} \\
(-1.68)\end{array}$ & - & $\begin{array}{l}0.023 \\
(0.41)\end{array}$ \\
\hline $\mathbf{R}^{2}$ & 0.885 & 0.764 & 0.914 & 0.926 & 0.688 & 0.582 \\
\hline $\begin{array}{c}\text { Sargan } \\
\text { test: } \\
\chi^{2}(335) \\
\end{array}$ & & 112.0 & & 130.9 & & 143.2 \\
\hline SC: AR(1) & -1.324 & -1.594 & -0.877 & -1.382 & 0.799 & -1.801 \\
\hline SC: $\mathbf{A R}(2)$ & 1.374 & 1.264 & 1.122 & -1.098 & 1.560 & 1.202 \\
\hline
\end{tabular}

Notes: t-ratios in parentheses, calculated from robust standard errors. SC:AR(1) and SC:AR(2) are tests for serial correlation up to $1^{\text {st }}$ and $2^{\text {nd }}$ order. The test statistics are distributed as $\mathrm{N}(0,1)$. The labels "a" and "b" denote significance at the $5 \%$ and $10 \%$ level, respectively. DF denotes degrees of freedom. 


\section{Data Appendix}

\begin{tabular}{|c|c|}
\hline $\mathrm{F}$ & $\begin{array}{l}\text { Log of real FDI flows for the whole UK manufacturing and its high and low R\&D } \\
\text { sectors. Source countries are the USA, France, Germany, the Netherlands, } \\
\text { Switzerland, Australia and Japan. Deflated by the domestic private fixed investment } \\
\text { deflator, 1995=100. Source: Office for National Statistics (ONS). High R\&D and low } \\
\text { R\&D FDI values are identified from data on R\&D expenditure published in } \\
\text { 'Research and Development in UK Businesses', Business Monitor MA14 (ONS) from } \\
\text { the Standard Industrial Classification (1992) sectors. The high R\&D industries are } \\
\text { chemicals, plastics and fuels; metal and mechanical products; office and IT } \\
\text { equipment; and transport equipment. The low R\&D sectors are food products; } \\
\text { textiles, wood and printing and publishing; and other manufacturing. }\end{array}$ \\
\hline ds & $\begin{array}{l}\text { Log of distance between the partner country's capital city and London in kilometres. } \\
\text { Source: http://www.eiit.org. }\end{array}$ \\
\hline re & $\begin{array}{l}\text { Log of the UK sterling real exchange rate vis-à-vis the source country's currency. } \\
\text { Defined as ep } / \mathrm{p} \text {, where e is the nominal exchange rate (the number of units of } \\
\text { foreign currency for each pound), } \mathrm{p}^{*} \text { is the foreign price level and p is the UK price } \\
\text { level (producer price indices used). Source: http://fx.sauder.ubc.ca/data.html, OECD } \\
\text { Main Economic Indicators and IMF International Financial Statistics }\end{array}$ \\
\hline $\mathrm{V}$ & $\begin{array}{l}\text { Exchange rate volatility. From the log of monthly real exchange rates, a GARCH } \\
(1,1) \text { model was estimated (see equation } 2 \text { ). An annual measure was constructed as } \\
\text { the sum of the monthly fitted GARCH values }\left(h_{t}\right) \text { for each year. }\end{array}$ \\
\hline$\dot{\mathrm{y}}$ & $\begin{array}{l}\text { Log of economic growth. Annual change in UK GDP per head, } 1995 \text { prices. Source: } \\
\text { ONS. }\end{array}$ \\
\hline $\operatorname{tr}$ & $\begin{array}{l}\text { Log of UK trade openness, defined as the ratio of total UK exports and imports to UK } \\
\text { nominal GDP. Source: IMF International Financial Statistics. }\end{array}$ \\
\hline$\left(r^{*}-r\right)$ & $\begin{array}{l}\text { Log of the real short-term interest rate differential. Interest rates on 3-month assets } \\
\text { were used, except for the Netherlands (call money rate adopted). Nominal interest } \\
\text { rates were deflated by the consumer price index }(1995=100) \text {. Source: OECD Main } \\
\text { Economic Indicators \& IMF International Financial Statistics. }\end{array}$ \\
\hline$\left(\mathrm{w}^{*}-\mathrm{w}\right)$ & $\begin{array}{l}\text { Log of real wage differential between source country and the UK. Nominal wage } \\
\text { indices, based on hourly, weekly or monthly earnings, deflated by a producer price } \\
\text { index and then converted into sterling. Source: OECD Main Economic Indicators, } \\
\text { IMF International Financial Statistics \& Swiss Federal Statistical Office. }\end{array}$ \\
\hline$\dot{\mathrm{sm}}$ & $\begin{array}{l}\text { Log change in Financial Times Ordinary industrial share price index }(1995=100) \text {. } \\
\text { Source: OECD Main Indicators \& IMF International Financial Statistics }\end{array}$ \\
\hline
\end{tabular}

